\title{
Comportamento Estratégico em Presidencialismo de Coalizão: As Relações entre Executivo e Legislativo na Elaboração do Orçamento Brasileiro*
}

\author{
Carlos Pereira e Bernardo Mueller
}

\section{INTRODUÇÃO}

T á uma forte recorrência na literatura que lida com variáveis po-

1 líticas relacionadas ao processo decisório orçamentário de que os países governados por coalizões multipartidárias geralmente apresentam níveis elevados de déficit público. Por isso, muitos autores defendem a tese de que os governos de coalizão se associam a custos mais altos do que os governos formados por partidos majoritários (Poterba, 1994). Roubini e Sachs, por exemplo, afirmam que:

"Quando o poder é disperso, seja entre esferas de governo (como nos Estados Unidos), seja entre muitos partidos políticos, em virtude da alternância de controle político ao longo do tempo, aumenta a probabilidade de ineficiência da política orçamentária. Assim, o tamanho e a persistência de déficits orçamentários em países industrializados na última década são maiores em governos divididos (isto é, coalizões multipartidárias em vez de um governo de partido majoritário)" (1989:905).

\footnotetext{
* Agradecemos os comentários e sugestões de Luiz Carlos Bresser Pereira, Marcus Melo, Adam Przeworski, Fernando Limongi e Lucio Rennó. [A tradução do original em inglês "Strategic Behavior in a Coalition-Based Presidential System: Executive-Legislative Relations in the Budgetary Process in Brazil" é de Vera Pereira.]
}

DADOS - Revista de Ciências Sociais, Rio de Janeiro, Vol. 45, no2, 2002, pp. 265 a 301. 
De acordo com a norma do universalismo, entendida como a reciprocidade na aprovação de programas distributivos entre parlamentares, os gastos crescem à medida que aumenta o número de legisladores e de partidos políticos. Assim, o orçamento aprovado por uma coalizão é maior do que o orçamento esperado de um partido majoritário no Congresso (Weingast, 1979; Shepsle e Weingast, 1981). Inman e Fitts (1990), por exemplo, demonstraram que quando um partido detém a maioria das cadeiras na Câmara dos Deputados a instabilidade do processo legislativo reduz-se. Em parlamentos multipartidários, conforme aumenta o número de partidos efetivos, as coalizões tornam-se instáveis e o tamanho do orçamento cresce como conseqüência da norma do universalismo (Scartascini e Crain, 2001) ${ }^{1}$.

Os sistemas eleitorais de representação proporcional com distritos de grande magnitude tendem a gerar sistemas políticos multipartidários e governos de coalizão (Lijphart, 1994). Além disso, nessa configuração há uma maior probabilidade de surgirem governos fracos do que nos sistemas pluralistas, uma vez que um grande número de partidos dificulta o controle do Congresso (Stein et alii, 1998). Ao discutir os problemas institucionais e de governabilidade no Brasil, Barry Ames afirma que eles decorrem do número excessivo de veto-players, conseqüência, sobretudo, do sistema eleitoral posto em prática e do federalismo. Na opinião dele, "raramente o presidente consegue evitar pagar um alto preço, na forma de clientelismo e fisiologismo, em troca de apoio parlamentar" (Ames, 2001:18). Supõe-se, portanto, que os governos de coalizão no Brasil convivem com grandes déficits. Para Mainwaring (1999), o uso político dos recursos públicos nas formas de patronagem, clientelismo e patrimonialismo não só implica um alto custo para o Brasil, como claramente impede que o governo priorize as preferências da maioria através de soluções coletivas.

É interessante notar que o Brasil "padece" de quase todas as "patologias" institucionais identificadas pela literatura como fatores responsáveis pela elevação do custo de governar: é um sistema presidencialista; uma federação; possui regras eleitorais que combinam sistema de lista aberta com representação proporcional; tem um sistema multipartidário com partidos políticos considerados débeis na arena eleitoral; e tem sido governado por uma ampla coalizão no Congresso. A soma destes fatores poderia gerar, se não uma democracia ingovernável, pelo menos muito dispendiosa, sobretudo no sentido de manter a unidade e a disciplina de sua coalizão. Mas, como será demonstrado, 
o custo da governabilidade, em termos de gastos orçamentários, tem sido muito baixo, quando comparado com outras despesas do governo (Figueiredo e Limongi, 2000). Este artigo, ao contrário da pressuposição da maioria da literatura que, basicamente, focaliza sua análise nos incentivos provenientes das regras eleitorais, argumenta que tem sido relativamente "barato" para o governo manter disciplinada sua coalizão no Congresso.

O objetivo aqui é analisar um dos mecanismos mais importantes de que o Executivo dispõe para negociar suas preferências com sua coalizão no Congresso: a execução das emendas individuais dos congressistas ao orçamento anual. O artigo descreve o processo de elaboração do orçamento no Brasil e aplica um modelo espacial para mostrar que as regras vigentes proporcionam ao Executivo instrumentos para controlar o processo, de modo a criar uma "moeda" política de baixo custo e extremamente útil para ser trocada por apoio político da sua coalizão no Congresso.

A próxima seção descreve as principais regras institucionais que regulam a iniciativa dos principais atores no Executivo e no Legislativo. Na terceira seção, o artigo desenvolve um modelo espacial para mostrar que as regras orçamentárias afetam os resultados da interação entre o governo e o Congresso. A quarta oferece evidências empíricas de que o Executivo usa estrategicamente a execução do orçamento como um dos mais importantes instrumentos de barganha na negociação do apoio do Congresso à sua governabilidade. A última destaca as conclusões mais importantes da aplicação do modelo e dos testes.

\section{O PROCESSO DE ELABORAÇÃO DO ORÇAMENTO NO BRASIL ${ }^{2}$}

Historicamente, o processo de elaboração do orçamento brasileiro tem alternado situações em que o Congresso efetivamente participa e define onde e como os recursos públicos são distribuídos e outras nas quais ele tem pouca ou nenhuma influência direta (ver Serra, 1994; Bezerra, 1999). Atualmente, mesmo quando os parlamentares têm um papel efetivo, este se limita essencialmente à proposição de emendas ao projeto de lei orçamentária que visam direcionar para suas bases eleitorais programas e projetos de interesse local.

A Constituição de 1988 gerou um novo conjunto de normas complexas para regulamentar o processo decisório do orçamento federal. $\mathrm{O}$ 
principal objetivo dessas inovações foi criar um sofisticado sistema hierárquico de coordenação e planejamento para um período de quatro anos, ampliando, assim, o ciclo orçamentário para além da formulação do projeto de lei anual (Rocha e Machado, 1995). Foram criados três instrumentos institucionais responsáveis pela regulamentação, planejamento e distribuição dos recursos federais: o Plano Plurianual - PPA, a Lei de Diretrizes Orçamentárias - LDO e a Lei Orçamentária Anual - LOA. Pela Constituição, esta tríade se liga hierarquicamente em diferentes etapas ${ }^{3}$.

As metas e diretrizes definidas pelo PPA e pela LDO são utilizadas pelo Executivo para elaborar o Projeto de Lei Orçamentária - PLO. Este projeto de orçamento estima o total das receitas e fixa as despesas para o exercício fiscal subseqüente, ou seja, a proposta detalha programas e atividades específicas que devem estar de acordo com os dois instrumentos mencionados. O presidente da República está obrigado a enviar para o Congresso o PLO até 30 de agosto e o prazo que este tem para emendar e aprovar o projeto se estende até 15 de dezembro. O exame da proposta é realizado pela Comissão Mista de Planos, Orçamentos Públicos e Fiscalização - CMPOF, sendo em seguida apreciado pelas duas Casas do Congresso. O PLO, posteriormente, é devolvido ao Executivo para sanção, com ou sem vetos ${ }^{4}$.

A Lei Orçamentária Anual é composta de três orçamentos diferentes: fiscal, da seguridade social e de investimentos das estatais. $\mathrm{O}$ orçamento fiscal abrange impostos e as despesas de toda a administração pública, incluindo os três Poderes e as fundações mantidas pelo Estado. O orçamento da seguridade social corresponde à ação do governo em três setores: saúde, previdência e assistência social. Por último, o orçamento de investimentos das estatais é responsável pelo montante total das receitas de $\operatorname{capital}^{5}$ (de origem não fiscal) a ser investido pelos órgãos públicos. Como será mostrado adiante, a rubrica "investimentos", constante nos três orçamentos, é um dos componentes mais importantes do orçamento federal, porque é basicamente aqui que se dá a participação dos parlamentares com a apresentação de emendas individuais e coletivas. A participação dos congressistas depende, portanto, da disponibilidade de recursos de investimentos, os quais se baseiam nas receitas de capital.

O Executivo é responsável pela coordenação e elaboração da Proposta de Orçamento Anual - POA, mais especificamente, compete à Se- 
cretaria de Orçamento Federal -SOF, do Ministério do Planejamento, Orçamento e Gestão, a coordenação e detalhamento da POA. A SOF estima o total de receitas e despesas de cada ministério (pessoal, contribuições previdenciárias, dívidas etc.), do Legislativo e do Judiciário. Na seqüência, define os parâmetros para todas as demais despesas, inclusive operacionais e de investimentos, além de especificar os limites de despesas para cada programa que cada um dos órgãos públicos se propõe a desenvolver. Após considerar esses limites orçamentários, cada ministério e órgão público devolve seu projeto à SOF, que fica com a responsabilidade de consolidar tudo em uma proposta única, o PLO, que é então encaminhado ao Congresso.

É importante notar que é nessa etapa que alguns parlamentares, especialmente os de mais prestígio e poder político, recorrem às suas redes políticas dentro dos ministérios e órgãos federais para incluir projetos de seu interesse na proposta que o Executivo deve enviar ao Congresso Nacional. Em outras palavras, esses parlamentares saltam um estágio importante das negociações no Congresso, fazendo constar seus pedidos já no projeto enviado pelo presidente da República. É nessa fase que se dão as negociações mais ardilosas dentro do Poder Executivo, com cada parte buscando alargar seu quinhão do orçamento e o Tesouro procurando conter as reivindicações de todos.

Mas o jogo orçamentário não acaba depois que o PLO é aprovado pelo Congresso e sancionado pelo presidente da República. Mesmo esgotadas essas etapas, ainda é possível modificar o projeto mediante créditos adicionais que abrem a possibilidade de introduzir novas emendas com potencial de redistribuir recursos. Esse mecanismo institucional torna o processo orçamentário quase interminável, convertendo-o em um jogo seqüencial em que Executivo e Congresso interagem em mais de uma ocasião. Conforme demonstraremos adiante, o Executivo participa desse jogo em uma posição mais favorável, pois se utiliza da assimetria de informações e de mecanismos institucionais que lhe outorgam consideráveis poderes discricionários.

Há três tipos de créditos adicionais: suplementares, especiais e extraordinários. Os créditos suplementares reforçam as alocações orçamentárias já incluídas na LOA quando o montante original de recursos é insuficiente para concluir o projeto. Se essa mudança está dentro dos limites estabelecidos pela LOA, os créditos suplementares significam basicamente uma redistribuição de recursos sem implicar no- 
vas despesas. Por essa razão, o crédito é autorizado por decreto presidencial e não requer aprovação do Congresso, o que confere ao Executivo um instrumento adicional para recompensar ou punir os parlamentares em função de como votam no Congresso.

Se a mudança desejada pelo Executivo ultrapassa o limite autorizado pela LOA, ou se corresponde a uma atividade ou projeto inteiramente novos, isto é, um gasto não associado a uma alocação orçamentária, é necessário que se crie um crédito especial. Nesse caso, é preciso enviar ao Congresso um novo projeto de lei que, por sua vez, deve ser aprovado pela Comissão Mista de Planos, Orçamentos Públicos e Fiscalização-CMPOF. Esta, todavia, não tem poderes nem para alterar a destinação de recursos nem para mudar a soma total do crédito proposto. Além disso, o crédito especial tem de ser aprovado por maioria simples do Congresso Nacional, o que não é difícil para um governo que possua uma maioria confortável de votos, como não raro tem acontecido.

Finalmente, o crédito extraordinário somente é utilizado em casos urgentes e não previstos tais como guerra, desastres naturais ou situação semelhante, e é autorizado por Medida Provisória. Em resumo: enquanto o crédito suplementar redistribui as despesas dentro dos limites previstos pela LOA, o crédito especial implica uma reformulação do orçamento, exigindo novas negociações com os parlamentares. As verbas a ser distribuídas via créditos adicionais originam-se basicamente do cancelamento de despesas previstas na LOA, de excedentes da arrecadação tributária e de empréstimos. Observe-se que o Executivo leva vantagem no processo por concentrar as informações sobre a disponibilidade de recursos no Tesouro Nacional.

A participação dos parlamentares no ciclo orçamentário tem lugar, sobretudo, na $\mathrm{CMPOF}^{6}$. Rocha (1997:108), ao comparar o número de emendas aprovadas pela CMPOF e pelo plenário do Congresso, chama a atenção para o fato de que o Congresso não modifica substancialmente o relatório ratificado pela comissão. De acordo com esse autor, a Comissão de Orçamento é o principal lócus decisório do orçamento no âmbito do Congresso (ver, também, Castro Santos e Machado, 1995). Trata-se da comissão mais numerosa, com 84 membros efetivos e 84 suplentes, 63 dos quais são deputados e 21 senadores. Sua composição baseia-se na proporção de cadeiras que cada partido político detém no Congresso, daí que os grandes partidos têm uma re- 
presentação maior na mesma. Segundo as normas internas do Congresso, os líderes partidários são responsáveis não só pela indicação dos membros da CMPOF, como também têm considerável influência na escolha do presidente e dos três vice-presidentes. Essas funções hierárquicas, mais a de relator, são alternadas a cada ano entre representantes do Senado e da Câmara dos Deputados. Dada a importância desses cargos, as prerrogativas dos líderes partidários na composição da comissão representam, para eles, um importante instrumento de controle do processo de elaboração do orçamento, assim como um meio de recompensar ou punir seus membros.

A CMPOF estrutura-se ainda em subcomissões temáticas formadas por, no máximo, sete parlamentares. Cada subcomissão tem um sub-relator setorial cuja responsabilidade é preparar um relatório parcial contendo as emendas a provadas por seus membros. O relator geral da CMPOF consolida todos esses relatórios. As funções de relator geral e de relator setorial são de grande influência e dependem de indicação do presidente da comissão, respeitando-se a norma da proporcionalidade entre os partidos.

Quando um projeto de lei chega à $\mathrm{CMPOF}$, o relator geral apresenta um parecer preliminar baseado nas negociações realizadas entre as lideranças dos partidos. Um dos aspectos mais importantes desse parecer é definir os parâmetros e prazos finais para que os parlamentares proponham emendas coletivas e individuais. Isto faz com que eles travem acirradas disputas para integrar a comissão e, principalmente, para ser nomeados para as principais funções hierárquicas, de relator e sub-relator. Seus ocupantes têm a prerrogativa de propor a redistribuição de verbas, já que o processo de aprovação de emendas é centralizado no relator. Além disso, somente os membros das comissões podem intitular as emendas durante o processo de votação no plenário da comissão ${ }^{7}$.

Embora os parlamentares tenham direito de propor emendas aos projetos de lei, cujo encaminhamento ao Congresso Nacional é direito exclusivo do presidente da República, eles somente podem fazê-lo se as emendas forem compatíveis com o Plano Plurianual elaborado pelo Executivo e com a Lei de Diretrizes Orçamentárias. Ademais, o Congresso pode não autorizar despesas que excedam a receita orçamentária. As normas sobre o processo de apresentação de emendas ao PLO têm variado muito nos últimos anos. Em 1992, somente eram 
aceitas emendas propostas individualmente pelos parlamentares. Em 1993, também as bancadas estaduais e outros grupos de congressistas podiam apresentar emendas coletivas. Para os orçamentos de 1994 e 1995, foram aceitos quatro tipos de emendas: de comissões permanentes, de partidos políticos, de bancadas estaduais e de parlamentares individuais. Com a Resolução no 2/95-CN, de 1996, as comissões permanentes, as bancadas estaduais e regionais e os parlamentares podem propor emendas.

As emendas coletivas têm mais chances de aprovação porque têm o apoio não só de indivíduos mas de um grupo que chegou a um acordo coletivo. Porém, a admissão de emendas coletivas não quer dizer que as individuais tenham desaparecido ou perdido importância. Não é raro que parlamentares entrem em acordo com políticos nos estados e municípios para propor emendas individuais - conhecidas como "rachadinhas" - disfarçadas de coletivas, pois consistem na apresentação de emendas genéricas ao orçamento, sem indicação do município onde será aplicado o recurso. Depois de aprovada a emenda, entretanto, os parlamentares enviam para o ministério responsável pela obra uma lista de municípios que deverão ser contemplados na hora da liberação da verba. De acordo com o deputado Sérgio Miranda (PC do B-MG), integrante da CMPOF,

"[...] é óbvio que há uso eleitoral, pois vincula a obra ao deputado ou senador. E são todas obras localizadas e em geral de baixo valor em dinheiro e grande apelo popular. Isso é uma distorção do espírito da emenda coletiva, criada para atender obras estruturais nos estados. Esta prática vem aumentando consideravelmente nos últimos anos, onde quase $40 \%$ das emendas coletivas estão sendo usadas para atender a obras eleitorais de deputados e senadores no Orçamento da União de 2002"8 (Folha de S. Paulo, Caderno Brasil, 13/11/2001).

Até 1993 não havia limite ao número de emendas que cada parlamentar podia propor ${ }^{9}$. A Resolução $\mathrm{n}^{\circ}$ 1/93 restringiu esse número a cinqüenta por parlamentar, em uma tentativa de racionalizar o processo, dando prioridade às emendas coletivas e refreando os numerosos conflitos entre os congressistas. Em 1995, a Resolução no 2/95-CN reduziu-o a vinte e estabeleceu um teto de $\mathrm{R} \$ 1,5$ milhão como valor total de emendas por parlamentar. Recentemente, este valor foi elevado para R\$ 2 milhões. É importante ter em mente, entretanto, que, ao compartilhar ou dar um uso individual às emendas coletivas, os par- 
lamentares conseguem extrapolar esse teto de $\mathrm{R} \$ 2$ milhões reservados para as emendas individuais.

A Resolução n 2/95-CN também estabeleceu novos limites ao número de emendas coletivas: cinco para as comissões permanentes, cinco para as bancadas regionais e dez para as bancadas estaduais. Contudo, mesmo com esse limite de valor e de número de emendas, os parlamentares não têm certeza de que suas propostas serão aprovadas pela Comissão Mista do Orçamento e, por isso, ainda precisam negociar com os relatores e líderes para que seus pedidos sejam aprovados na LOA, já que muitos são simplesmente deixados de lado.

Outra importante mudança institucional introduzida em 1995 foi a descentralização do poder dentro da CMPOF, com o aumento da autonomia dos relatores das subcomissões em relação ao relator geral da comissão, o qual perdeu a prerrogativa de apresentar emendas de relator e o direito de reapresentar emendas rejeitadas. Vale notar que a distribuição de poder dentro da comissão e das subcomissões não é equilibrada e depende da quantidade de recursos disponíveis. Assim, as subcomissões responsáveis pela definição da alocação de recursos para educação, saúde e infra-estrutura são muito mais disputadas. Os parlamentares muitas vezes contam com o apoio de seus prefeitos e governadores para fazer lobby dos seus pedidos no Congresso.

As mudanças introduzidas no funcionamento da comissão visando descentralizá-la, o aumento do poder dos sub-relatores e o estabelecimento de limites ao número de emendas tiveram o propósito de reduzir os custos de transação e os problemas de ação coletiva entre os congressistas. A intenção era redistribuir o poder no sentido de viabilizar o acesso eqüitativo aos recursos, aumentando com isso a probabilidade de aprovação mútua de emendas por acordo de apoio recíproco entre parlamentares [logrolling].

Entretanto, todos esses passos e complexas negociações para aprovar emendas não garantem que um projeto, uma vez aprovado e sancionado pelo presidente da República, seja realmente implementado. Embora os parlamentares tenham o direito de propor emendas individuais e coletivas ao orçamento anual, cabe ao Executivo determinar quais delas serão executadas, na dependência dos recursos disponíveis no Tesouro Nacional. 
A grande maioria dos parlamentares lança mão dessa prerrogativa para propor emendas destinadas a beneficiar suas principais bases eleitorais, isto é, essa estratégia é utilizada por uma política clientelista com o objetivo de maximizar o futuro eleitoral e a carreira do parlamentar. Dessa maneira, é plausível supor que o Executivo, que tem grande poder discricionário na execução do orçamento anual, use este poder para fazer pressão sobre a atuação dos parlamentares (Pereira, 2000).

É a falta de sincronia entre a arrecadação fiscal e as despesas previstas que permite ao Executivo agir estrategicamente ao contingenciar a liberação das emendas à disponibilidade de recursos. Em conseqüência disso, o Executivo usa de extrema flexibilidade e arbítrio na negociação com os parlamentares, ao não aplicar critérios homogêneos quando decide sobre as emendas que serão de fato executadas. As evidências apresentadas neste artigo demonstram que o presidente da República recompensa os parlamentares que sistematicamente votam a favor dos projetos de interesse do governo, autorizando a execução de suas emendas individuais, e, ao mesmo tempo, pune os que não votam nesses projetos simplesmente não executando as emendas propostas por eles. $\mathrm{O}$ artigo afirma ainda que, mantidas constantes as demais condições, quanto maior o valor das emendas executadas de um congressista, maiores são suas chances de reeleição (Pereira, 2000; Pereira e Rennó, no prelo).

Em outras palavras, em face desse arcabouço institucional, não admira que alguns parlamentares votem sistematicamente nos projetos do governo, porque sabem que tal comportamento aumenta a probabilidade de os seus pedidos serem atendidos pelo chefe do Executivo. Por outro lado, os parlamentares que não acompanham com tanta freqüência as preferências do governo têm menos possibilidades de implementar programas e projetos que beneficiem seu eleitorado.

Aqui, procuramos responder por que os parlamentares se contentam com um papel tão reduzido no processo de elaboração do orçamento e por que a maioria dos parlamentares não tenta alcançar um melhor equilíbrio no que diz respeito ao acesso aos recursos públicos. A resposta é que esse papel, mesmo que limitado, proporciona altos retornos eleitorais, pois quanto mais emendas individuais são executadas, maiores serão as chances de reeleição do parlamentar. 


\section{A INTERAÇÃO EXECUTIVO/LEGISLATIVO NO PROCESSO ORÇAMENTÁRIO}

Esta seção apresenta um modelo espacial sobre a interação do Congresso com o Executivo na elaboração e execução do orçamento anual brasileiro. O modelo parte de um cenário muito simplificado em que o Executivo não tem poder para evitar que o Congresso altere seu projeto de orçamento. Nessas condições irrealistas, o Executivo não possui meios para impedir que o Congresso mude o orçamento para um ponto distante das preferências do governo, mais próximo ao ponto preferido por uma maioria do Congresso. Depois, passo a passo, o modelo vai atribuindo ao Executivo uma série de poderes e examina como cada uma dessas salvaguardas o habilita a proteger sua proposta original de possíveis alterações produzidas no Legislativo, sendo que cada uma delas representa normas e procedimentos do processo orçamentário brasileiro atual. Em conjunto, essas regras significam que o Executivo corre poucos riscos de ter a proposta alterada contra sua vontade.

Para simplificar, vamos supor que o orçamento contenha somente duas políticas públicas diferentes, a política 1 e a política 2. Suponhamos ainda que existam apenas três congressistas, A, B e C, cujos pontos de preferência estão representados na Figura 1. A figura está desenhada de forma a sugerir que A prefere um investimento mais alto na política 1, B opta por mais recursos para a política 2 e C fica com um nível de preferência relativamente baixo com relação a ambas, sendo assim um conservador do ponto de vista fiscal. Como já foi dito na seção anterior, o Executivo tem a prerrogativa de elaborar o orçamento a partir de previsões do total das receitas e das despesas para o ano fiscal subseqüente. Suponha-se que o resultado desse procedimento seja um orçamento representado pelo ponto $Q_{0}$ na Figura 1. Para mostrar a preferência de cada parlamentar, marcamos a localização dos seus pontos de indiferença em relação ao ponto $Q_{o}$. Os pontos que estão dentro da curva de indiferença são preferidos aos que estão sobre ou além dela. As curvas foram desenhadas com a forma de elipses para mostrar que A se importa mais com a política 1 e B com a política 2. Quanto mais alongadas são as elipses, mais acentuadas são as preferências por uma das políticas públicas ${ }^{10}$.

Vamos abstrair por um momento o papel da CMPOF na avaliação de emendas à proposta orçamentária do Executivo e supor que elas foram 
Figura 1

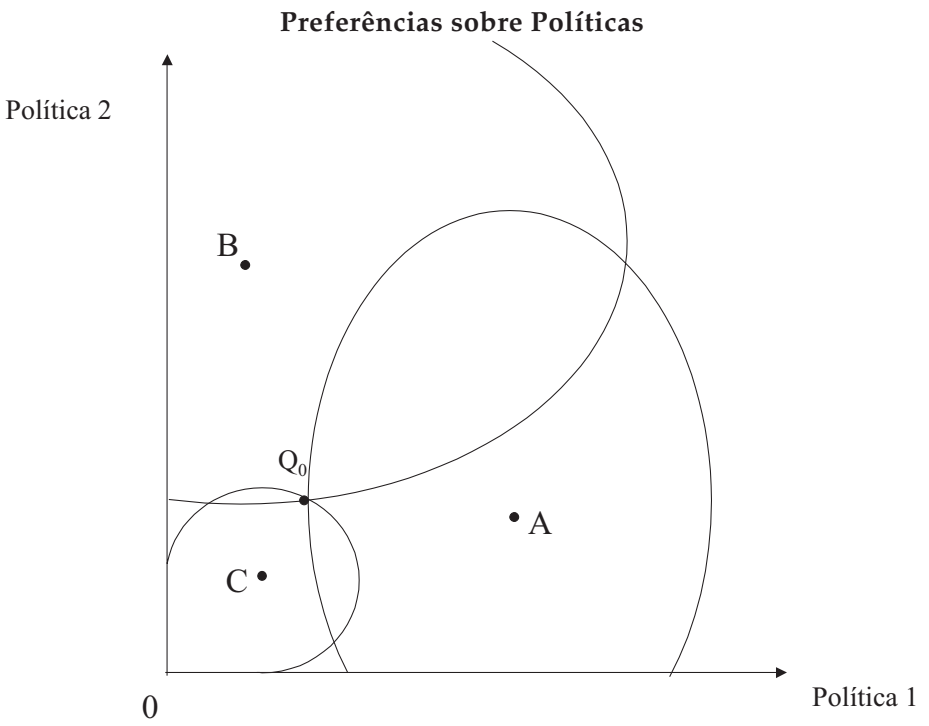

aprovadas pela maioria do Congresso. Na Figura 2, as curvas de indiferença estão truncadas para mostrar somente as três pétalas formadas pela série de pontos que levam uma maioria de parlamentares a votar contra o ponto $Q_{o}$, isto é, o win-set do ponto $Q_{o}$ ou $W\left(Q_{o}\right)$. Mas nem todos os pontos em $W\left(Q_{o}\right)$ são viáveis. Os pontos em $W\left(Q_{o}\right)$ em que pode haver emendas dependem das normas de elaboração do orçamento. Vamos imaginar agora que o nível inicial de despesas determinado pelo Executivo não pode ser aumentado, mas somente realocado. A linha $\mathrm{P}_{0}^{1}-\mathrm{P}_{0}^{2}$ representa uma restrição que limita os pontos em que é possível acrescentar emendas à proposta original. Esta linha tem uma inclinação de -1, indicando que para acrescentar um dólar a uma dada política, quantia equivalente terá de ser subtraída de uma outra. Todos os pontos abrangidos pelo triângulo $0 \mathrm{P}_{0}^{1}-\mathrm{P}_{0}^{2}$ são viáveis.

A Figura 2 também mostra a curva de contratos entre cada dupla de parlamentares (linhas pontilhadas). Estas linhas mostram a localização dos pontos ótimos de Pareto para cada dupla de congressistas, isto é, os pontos em que nenhuma mudança pode ser melhor para pelo menos um dos dois sem prejudicar o outro. Se as curvas de indiferença fossem círculos perfeitos, as curvas de contrato seriam linhas retas. A forma arredondada dessas curvas deve-se às preferências elípticas. Se qualquer dupla de congressistas formasse uma aliança 
Figura 2

Processo de Emendas Orçamentárias com Restrição

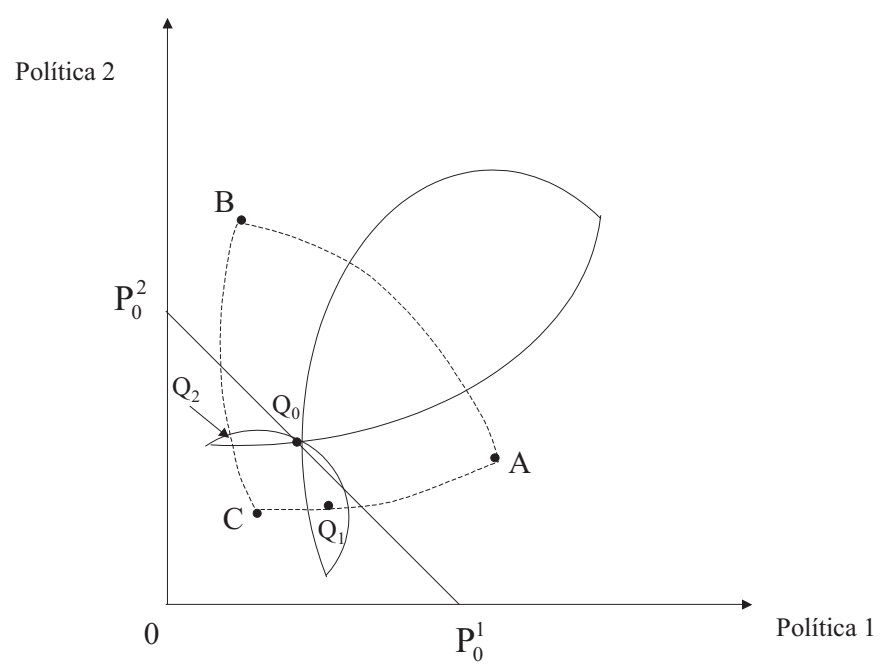

para emendar o orçamento, poder-se-ia esperar que escolhesse um ponto dentro da pétala formada por suas curvas de indiferença em relação a $Q_{0}$, que também está na curva de contrato.

Dada a configuração de preferências mostrada na Figura 2, o orçamento inicial proposto pelo Executivo em $\mathrm{Q}_{0} \mathrm{e}$ a restrição à criação de novas despesas, que emendas se poderia esperar que o Congresso aprovasse? Sem outras instituições restringindo a seqüência de ações ou estabelecendo pontos de veto, não é possível fazer uma previsão única que identifique como ficaria o orçamento. Isto é, nas condições desse modelo simplificado, não temos elementos suficientes para assegurar uma estrutura de equilíbrio para o processo de emenda do orçamento (Shepsle e Weingast, 1981). Entretanto, é possível fazer algumas previsões a respeito da série de pontos em que o orçamento pode ser emendado. Eles devem estar na interseção do triângulo $0 \mathrm{P}_{0}^{1}-\mathrm{P}_{0}^{2}$, nas pétalas formadas pelas curvas de indiferença que atravessam $\mathrm{Q}_{0} \mathrm{e}$ nas curvas de contrato. Supõe-se, portanto, que pontos como $Q_{1}$ ou $Q_{2}$ possam resultar da formulação de emendas pelos parlamentares ${ }^{11}$.

Note-se que o orçamento emendado pode ficar muito diferente do que o Executivo tinha originalmente encaminhado ao Congresso. Isto significa que, nas condições aqui pressupostas, o governo correria o risco de ser passado para trás pelo Congresso. Mas não é isto que se vê 
normalmente no Brasil, nem é um resultado compatível com a preponderância do Executivo em suas relações com o Congresso (Pereira e Mueller, 2000).

A seguir, introduzimos no modelo regras mais realistas para fazê-lo refletir com mais propriedade sobre a real tramitação do orçamento no Congresso brasileiro.

\section{Veto Presidencial}

Na realidade, o presidente pode vetar a proposta de orçamento que recebeu emendas no Congresso. O veto pode valer para toda a proposta ou para partes selecionadas, o que confere ao presidente um considerável controle sobre o desenho final do orçamento. Se o veto do presidente fosse isento de custos, o orçamento acabaria mantendo sua forma original $Q_{0}$. Neste caso, o Congresso nem se daria ao trabalho de propor emendas na certeza de que seriam vetadas. $O$ fato de $\mathrm{o}$ orçamento receber tantas emendas sem serem vetadas sugere duas explicações possíveis. A primeira é que embora as emendas afastem o projeto do ponto preferido pelo governo, o presidente pode sair beneficiado, porque a execução das mesmas aumenta seu cacife na barganha com os parlamentares. A segunda explicação é que vetar emendas apresenta um alto custo político para o governo por desencadear a oposição de um determinado grupo em função do corte de um programa de seu interesse. Se há um veto total, o custo pode ser ter de reiniciar toda a tramitação da proposta orçamentária e correr o risco de começar o novo ano fiscal sem um orçamento aprovado. Com a Figura 3 acrescentamos em nossa análise o custo do veto ao serem definidos um conjunto de pontos de não-reversão em torno de $Q_{0}$. Estes pontos representam as emendas que o governo gostaria de vetar, cujo custo, no entanto, é maior do que o benefício de trazer o orçamento de volta à forma original, em $\mathrm{Q}_{0}$. Observe-se que esse conjunto de pontos foi desenhado na Figura 3 de modo a indicar que as emendas que mudam o orçamento de $Q_{0}$ para $Q_{1}$ seriam vetadas, mas não as que poriam o orçamento no nível $Q_{2}$.

\section{Restrições Moderadas às Emendas do Orçamento (Soft Budget Constraint)}

Uma importante diferença entre o cenário acima descrito e o processo real de tramitação do projeto orçamentário no Brasil é que os parla- 
Figura 3

Vetos com Custos

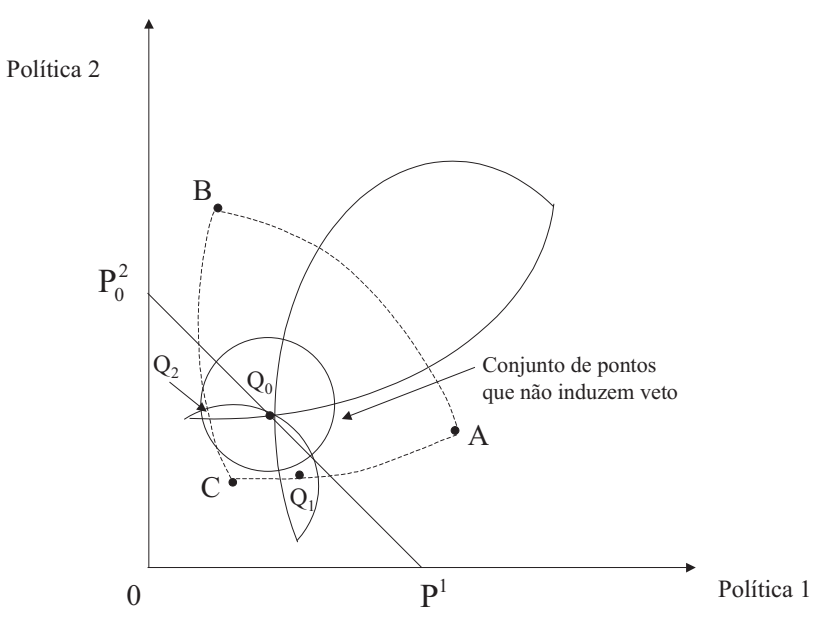

mentares podem alterar o PLO ao propor emendas que incorrem em novas despesas no orçamento. Dissemos na seção anterior que cada parlamentar tem o direito de propor no máximo vinte emendas, até o valor de R $\$ 2$ milhões. A Figura 4 mostra os efeitos dessa mudança no resultado esperado do processo orçamentário. Se até então a política aprovada devia estar dentro dos limites do triângulo definido pela linha $\mathrm{P}_{0}^{1}-\mathrm{P}_{0}^{2}$, que corta a proposta inicial do governo, a possibilidade de acrescentar nova despesa abranda essa restrição a uma linha como a $\mathrm{P}_{1}^{1}-\mathrm{P}_{1}^{2}$. Isso permite que $\mathrm{A}$ e $\mathrm{B}$ se aliem em torno de um ponto dentro da pétala formada por suas curvas de indiferença, através de $Q_{0}$, até um ponto como, por exemplo, $\mathrm{Q}_{3}$. Admitindo-se um volume das novas despesas suficientemente grande para empurrar o limite do orçamento para $\mathrm{P}_{2}^{1}-\mathrm{P}_{2}^{2}$, os congressistas $\mathrm{A}$ e $\mathrm{B}$ até poderiam chegar ao ponto $Q_{4}$ de sua curva de contrato, ainda que não se possa afirmar com segurança se o resultado final será um ponto perto de $Q_{1}$, de $Q_{2}$ ou de $\mathrm{Q}_{4}$. Seja como for, a possibilidade de acrescentar novas despesas aumenta o perigo de o Congresso desfigurar a proposta inicial do Executivo.

Na realidade, observa-se que em todos os anos os parlamentares acrescentam uma grande quantidade de emendas ao orçamento, o que nos leva a crer que os pontos $Q_{3}$ e $Q_{4}$ podem ser realmente alcançados. No entanto, em vez de aceitar a idéia de que o Executivo é enganado pelo Congresso, propomos uma explicação diferente. Mais uma vez, o fato 
Figura 4

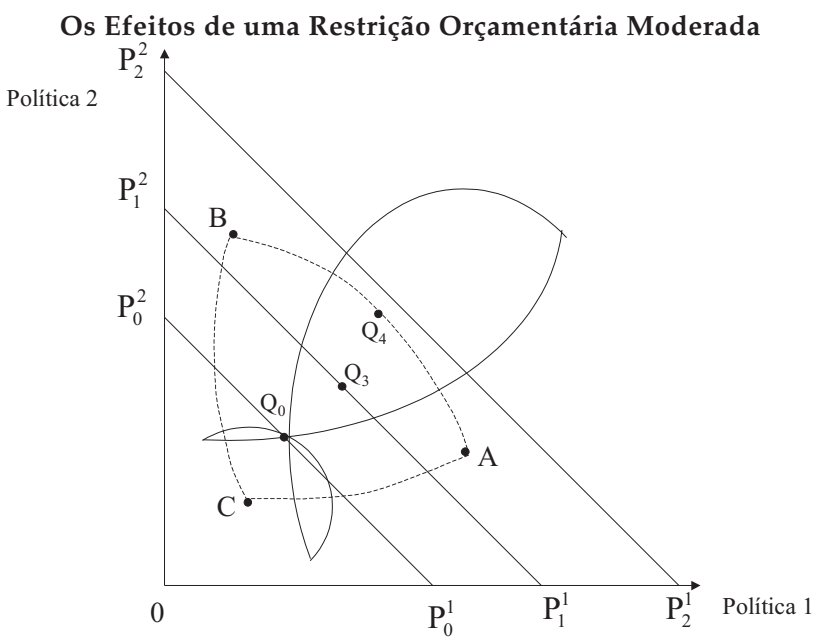

de o Executivo concentrar poderes e instrumentos para proteger seus interesses, não só em matérias orçamentárias, mas em todos os demais processos legislativos, faz-nos supor que se os pontos $Q_{3}$ e $Q_{4}$ podem ser alcançados é que estes resultados devem trazer vantagens para o governo. Para entender isso, precisamos, em primeiro lugar, descrever duas possibilidades de o Executivo permitir emendas e ao mesmo tempo manter o controle sobre o processo de execução do orçamento, de modo a evitar conseqüências indesejáveis.

\section{A Comissão Mista do Orçamento}

Vimos que a CMPOF concentra o poder decisório sobre o orçamento no interior do Congresso. Dissemos também que determinados cargos na comissão (presidente, vice-presidente, relator geral e relator setorial) têm meios para exercer considerável influência no processo de emendar o orçamento federal. Visto que as nomeações para esses cargos são feitas pelas lideranças partidárias, respeitando o tamanho relativo de cada legenda no Congresso, são os líderes dos partidos que compõem a base de sustentação do governo que, na realidade, detêm o controle sobre o processo de elaboração do orçamento, porque eles têm uma confortável maioria no Legislativo.

Essas circunstâncias impõem novas limitações ao resultado da interação entre os parlamentares para propor emendas. Supondo-se que o poder da Comissão do Orçamento lhe confere bastante controle sobre 
o processo, não é de se esperar que o orçamento modificado seja pior para a Comissão do que a proposta original do Executivo. Na hipótese de o congressista $C$ da Figura 4 deter os poderes da Comissão, pode-se prever que o orçamento emendado esteja mais perto do ponto preferido de $C$ do que $Q_{0}$. Isto é, se $A$ e $B$ tentarem emendar o orçamento para um ponto como $\mathrm{Q}_{3}$ ou $\mathrm{Q}_{4}$, Comissão poderá impedir essas propostas. Resultados que tornem a Comissão pior do que o ponto $\mathrm{Q}_{0}$ só serão observados se ela permitir que isso aconteça, o que será feito somente se os custos dessa decisão forem compensados por outros meios. Argumentaremos abaixo que é exatamente isso que tem ocorrido.

\section{Restrições Relativas aos Tipos de Políticas que Podem Receber Emendas no Congresso}

Dada a estrutura institucional atual, o Executivo tem vários instrumentos para garantir o controle do processo de emendas do orçamento no Congresso. O Executivo não somente detém a prerrogativa exclusiva de determinar o status quo, ao escolher $\mathrm{Q}_{0}$, mas também de estabelecer as diretrizes do processo em combinação com a sua coalizão majoritária que controla a Comissão do Orçamento. E se tudo isso falhar, o governo pode vetar as emendas, total ou parcialmente. Mas existem ainda outras salvaguardas no processo de aprovação do orçamento que impedem que o Congresso modifique a proposta do governo. Conforme foi visto na seção anterior, a maioria das despesas previstas na proposta original não é passível de emenda por parte dos congressistas. As regras determinam que o Congresso só pode influir nos recursos da rubrica investimentos, que tem respondido por apenas $1 \%$ a $2 \%$ de todas as despesas orçamentárias. Isso quer dizer que os parlamentares, na realidade, têm muito pouca influência no orçamento total. A maior parte dos itens está não só além do alcance das emendas dos parlamentares, como a parcela que pode sofrer emendas é rigidamente controlada pelo Executivo.

\section{Utilização Estratégica da Apropriação das Emendas}

Se as regras conferem ao Executivo todo esse controle sobre o processo de aprovação do orçamento, é estranho que tantas emendas sejam propostas pelos congressistas. Mesmo que elas só possam ter como alvo uma faixa reduzida de despesas (investimentos), ainda assim representam importantes recursos que se esperaria que o governo qui- 
sesse usar segundo suas preferências. Estamos sugerindo que o governo tem bons motivos para permitir que os parlamentares emendem o orçamento, mesmo que isso no mais das vezes signifique que os recursos sejam gastos de maneira diferente do que o Executivo gostaria. A razão disso é que a aprovação de emendas não é o passo final no processo orçamentário. Mesmo depois de aprovado, inclusive com as emendas apresentadas, a efetiva implementação dos programas e projetos não está garantida. Cabe ao Executivo a incumbência de liberar os recursos para as despesas especificadas no orçamento. $\mathrm{E}$ as regras concedem ao governo uma grande parqueza na decisão de quando e quanto será executado. Em conseqüência, o Executivo pode escolher estrategicamente quais emendas de um político serão apropriadas ou engavetadas, apesar de ter sido aprovadas. Isso põe nas mãos do governo um importante instrumento para recompensar ou punir os congressistas de acordo com o grau de apoio ou de oposição que lhe proporcionam durante o ano. Alston e Mueller (2001) desenvolveram um modelo para explicar a interação do Executivo brasileiro com sua coalizão no Congresso, e demonstraram que o uso estratégico da execução das emendas dos congressistas é uma importante moeda para incentivar esses atores a cooperar. A apropriação das emendas é um dos principais meios usados pelo governo em troca de apoio a suas propostas. Ao negociar suporte político em troca de patronagem, o Executivo e sua coalizão conseguem colher os lucros no "mercado" legislativo, o que foi crucial para que o governo conseguisse aprovar importantes reformas na década de 90. Fica evidente que o Executivo tem bons motivos para permitir que os congressistas proponham emendas ao orçamento. A perda de recursos orçamentários é mais do que compensada pelo apoio obtido pelo governo em troca da apropriação estratégica de emendas.

\section{UTILIZAÇÃO ESTRATÉGICA DAS EMENDAS ORÇAMENTÁRIAS DO CONGRESSO}

Nesta seção apresentamos dados que comprovam que o Executivo permite deliberadamente que os parlamentares façam emendas ao orçamento a fim de usar estrategicamente a apropriação destas como mecanismo para coordenar e disciplinar a sua coalizão no Congresso. O primeiro teste desta hipótese compara dados de votações nominais de cada membro da Câmara dos Deputados com a proporção de emendas individuais efetivamente executadas em relação às que ti- 
nham sido propostas pelos parlamentares e aprovadas pelo Congresso. A idéia é fazer uma regressão da proporção de emendas apropriadas em comparação com uma variável que mede a freqüência com que o congressista seguiu a indicação do líder do governo no plenário da Câmara dos Deputados ${ }^{12}$. Controlando outras variáveis que possam influenciar na decisão do governo de executar as emendas de um parlamentar, é possível testar se o modo como os congressistas votam influi na decisão do governo. O cálculo dessa relação por mínimos quadrados ordinários (OLS) pode não gerar resultados confiáveis já que há motivos para crer que o erro da regressão se correlaciona à variável votação nominal do parlamentar. Supõe-se que não apenas a forma de votar afeta a execução das emendas, mas que um parlamentar, cujas emendas fossem executadas, tenderia, ceteris paribus, a votar com mais freqüência a favor do governo. Existem, portanto, duas variáveis endógenas e é preciso, então, calcular um sistema de equações que as determine. O sistema, que pode ser fixado por um estimador de variáveis instrumentais, é o seguinte:

Execução $_{i}=\beta_{0}+\beta_{1}$ Votos $_{i}+\beta_{2}$ Número de Emendas En $_{i}+\beta_{3}$ Antiguidade $_{i}+\beta_{4}$ $\operatorname{Cargo}_{i}+\varepsilon_{\mathrm{i}}$

Votos $_{i}=\alpha_{0}+\alpha_{1}$ Execução $_{i}+\alpha_{2}$ Cargo $_{i}+\alpha_{3}$ Concentração $_{i}+\alpha_{4}$ Esquerda $_{i}+\alpha_{4}$ Centro $_{i}+v_{\mathrm{i}}$

A variável Execução ${ }_{i}$ é a porcentagem de todas as emendas propostas por um deputado e aprovadas no Congresso que o governo efetivamente executou ${ }^{13}$. Quando um grande número de emendas aprovadas não é executado, o governo na realidade está premiando os parlamentares com uma taxa elevada de execuções ${ }^{14}$.

A primeira equação controla o número de emendas propostas pelo deputado por meio da variável Número de Emendas. A segunda variável endógena é $V_{0 t o s}$, que mede a porcentagem de votos (em 325 votações nominais) favoráveis ao governo dados por parlamentares. Como tal, esta variável pode ser entendida como um indicador da lealdade/apoio ao Executivo (Pereira e Mueller, 2000). Um coeficiente positivo e significativo sugere que o governo leva em conta o modo como o deputado vota ao decidir quais de suas emendas serão execu-

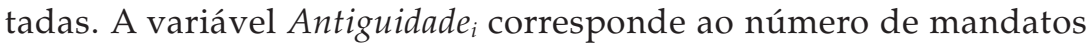
anteriores do parlamentar. Sua inclusão na primeira equação tem o objetivo de controlar o efeito dessas experiências sobre a capacidade 
de os parlamentares terem executadas suas emendas. A última variável na primeira equação, $\operatorname{Cargo}_{i}$, é uma variável dummy que vale 1 se o congressista $i$ já foi presidente ou vice-presidente de uma comissão permanente ou especial. O objetivo dessa variável é verificar se os congressistas que ocuparam cargos importantes na hierarquia parlamentar também se saem bem na execução de suas emendas.

A segunda equação tem $\operatorname{Votos}_{i}$ no seu lado esquerdo e como principal variável explicativa Execução $\mathrm{o}_{\mathrm{i}}$. Se o coeficiente é positivo e significativo, pode-se concluir que o governo influi no modo de votar dos congressistas, escolhendo estrategicamente quais emendas serão executadas e quais serão engavetadas. Incluímos a variável $\mathrm{Cargo}_{i} \mathrm{Com}$ a finalidade de controlar outros determinantes do padrão de voto, bem como a variável Concentração $o_{i}$ que mede a porcentagem de votos recebidos pelo deputado $i$ na eleição de 1994 no município onde ele obteve a maioria dos seus votos ${ }^{15}$. Esta variável captura o efeito da influência direta da base eleitoral na maneira como os parlamentares votam no Congresso. Geralmente, pensa-se que quanto maior é a concentração do eleitorado de um deputado, mais próximo ele ficará de sua base eleitoral. Por isso, será muito difícil para ele votar a favor dos interesses do governo, mais provável é que ele se alinhe com as preferências de sua base eleitoral. Por último, controlamos a filiação partidária do deputado com variáveis dummy para partidos de esquerda e de centro, ficando os partidos de direita como a categoria deixada de fora. Essas variáveis partidárias devem controlar uma grande diversidade de características do parlamentar sobre as quais não dispomos de dados específicos. Os resultados da regressão são exibidos na Tabela 1 .

Para garantir estimadores consistentes, dada a simultaneidade entre $\operatorname{Votos}_{i}$ e Execução ${ }_{i}$, usamos variáveis instrumentais, isto é, variáveis que tenham correlação com a variável endógena do lado direito de cada equação, mas não se correlacionam com o termo de erro ${ }^{16}$. Os resultados mais importantes das regressões são os coeficientes positivos e significativos da variável Voto e da variável Execução de emendas nas duas equações. Estes coeficientes mostram que mesmo controlando o poder de outras variáveis que possam influir na decisão do governo de executar ou não as emendas de um parlamentar, a freqüência com que o deputado vota a favor do governo aumenta a probabilidade de as suas emendas serem executadas. Da mesma forma, quanto maior a proporção de emendas executadas de um deputado, 
Tabela 1

Relação entre o Apoio do Deputado ao Governo e a Proporção de Emendas desse Deputado que São Executadas

(1995-1998)

\begin{tabular}{l|c|c}
\hline & $\begin{array}{c}\text { Variável Dependente: } \\
\text { Votos }\end{array}$ & $\begin{array}{c}\text { Variável Dependente: } \\
\text { Execução }\end{array}$ \\
\hline Constante & $43,60^{* * *}$ & $14,52^{* * *}$ \\
Execução & $(2,79)$ & $(3,03)$ \\
Votos & $0,882^{* * *}$ & \\
Cargo & $(2,76)$ & $0,321^{* * *}$ \\
Concentração & & $(6,19)$ \\
& 1,54 & $-0,613$ \\
Esquerda & $(0,75)$ & $(-0,367)$ \\
& $0,179^{* *}$ & \\
Centro & $(2,264)$ & \\
Número de emendas & $-29,86^{* * *}$ & \\
Antiguidade & $(-6,32)$ & $-0,163$ \\
\hline R & $-1,74$ & $(-0,700)$ \\
$\mathbf{N}$ & $(-0,864)$ & 0,038 \\
\hline
\end{tabular}

Fonte: Câmara dos Deputados.

Obs.: Estimativa de variáveis instrumentais t-stat. Os valores entre parênteses referem-se ao grau de significância estatística: $1 \% * *, 5 \% * *$. A matriz de co-variância é uma matriz de heterocedasticidade forte corrigida de White (1980).

mais vezes ele votará com o governo. É claro que outros fatores, além dos incluídos nessas regressões, também influem na escolha do governo de quais emendas executar e na decisão do deputado de como votar, conforme indica o $\mathrm{R}^{2}$ relativamente baixo. Entretanto, os resultados são compatíveis com o argumento deste artigo de que as emendas ao orçamento propostas individualmente pelos parlamentares são usadas pelo governo como instrumento de incentivo em troca do apoio aos projetos de interesse do Executivo no Congresso.

A variável Concentração também apresenta um coeficiente positivo e estatisticamente significativo na equação sobre o padrão de voto dos parlamentares. Isso indica que é mais provável que os parlamentares 
que tiveram votação mais concentrada na eleição anterior votem de acordo com as preferências presidenciais. Em outras palavras, ao contrário do que se esperava, os deputados que tinham bases eleitorais mais concentradas tenderam a ser mais favoráveis às preferências do governo. Isso nos leva a crer que esses deputados dependem mais dos benefícios que trazem às suas bases do que aqueles cujo eleitorado é mais disperso. Confirmando nossa hipótese, a variável Esquerda obteve um coeficiente negativo e significativo, o que implica dizer que esses deputados tendem a votar contra as preferências do Executivo.

Outra importante indicação da influência do presidente no padrão de voto dos parlamentares foi a decisão do governo Fernando Henrique de centralizar a distribuição de recursos sob o controle do Executivo criando o Sistema de Acompanhamento Legislativo - SIAL (decreto no 1.403, de 21 de fevereiro de 1995). Com essa mudança, o governo FHC inaugurou uma forma nova e eficiente de controlar ao mesmo tempo os pedidos e o comportamento dos deputados. Na opinião de Eduardo Graeff, secretário executivo da pasta de Assuntos Institucionais:

“No início do governo, tínhamos notado que faltava um mecanismo institucional capaz de controlar os pedidos dos parlamentares. Não era raro ver diversos deputados, muitos deles infiéis ao governo, solicitando a ajuda de diferentes ministérios e órgãos do governo para seus distritos eleitorais. Foi por isso que resolvemos assumir o controle dessa situação centralizando todos os pedidos dos parlamentares no SIAL. Esse sistema centralizado nos permite formar um quadro exato do que os deputados pediram bem como da medida em que o governo atendeu a esses pedidos"17.

Em outras palavras, o SIAL faz um balanço entre os pedidos dos deputados e a maneira como votam no Congresso. Isso ajuda a racionalizar e controlar as despesas orçamentárias do Executivo, reduzindo os custos da busca de apoio ao permitir que o governo responda aos pedidos de deputados que lhe são fiéis, ao mesmo tempo que evita o desperdício de verbas com parlamentares infiéis.

Portanto, os parlamentares que costumavam operar com suas redes de influência nas burocracias dos diversos ministérios para ter acesso aos recursos públicos agora têm de tratar diretamente com a Secretaria Geral da Presidência da República, que dispõe de informações 
completas sobre o que eles desejam e como se comportam no Congresso. Essa nova estrutura enfraqueceu ainda mais o poder de barganha dos parlamentares na negociação com o governo, que deixa estrategicamente para o último mês do ano fiscal a recompensa aos deputados fiéis. Nos três últimos anos fiscais, por exemplo, mais de dois terços (66,9\% em 1999, 66,0\% em 2000 e 74,1\% em 2001) das execuções do orçamento da rubrica investimentos foram feitas em dezembro, a maior parte como "restos a pagar" a serem efetivamente liberados no ano fiscal subseqüente. Quer dizer, a estratégia do governo é esperar até o último momento para executar investimentos orçamentários, inclusive emendas individuais ou coletivas dos parlamentares, como forma de pressioná-los a votar de acordo com as preferências do Executivo ao longo do período legislativo.

Tabela 2

Distribuição Temporal dos Desembolsos de Recursos de Investimento pelo Executivo (R\$ milhões)

\begin{tabular}{l|c|c|c|c}
\hline & $\mathbf{1 9 9 8}$ & $\mathbf{1 9 9 9}$ & $\mathbf{2 0 0 0}$ & $\mathbf{2 0 0 1}$ \\
\hline \multirow{2}{*}{ Desembolso janeiro/novembro } & 4.758 & 2.304 & 3.429 & 3.775 \\
& $57,0 \%$ & $33,1 \%$ & $33,9 \%$ & $25,9 \%$ \\
\multirow{2}{*}{ Desembolso dezembro } & 3.588 & 4.651 & 6.670 & 10.805 \\
& $43,0 \%$ & $66,9 \%$ & $66,0 \%$ & $74,1 \%$ \\
\hline \multirow{2}{*}{ Total } & $\mathbf{8 . 3 4 6}$ & $\mathbf{6 . 9 5 5}$ & $\mathbf{1 0 . 0 9 9}$ & $\mathbf{1 4 . 5 8 0}$ \\
& $\mathbf{1 0 0 , 0 \%}$ & $\mathbf{1 0 0 , 0 \%}$ & $\mathbf{1 0 0 , 0 \%}$ & $\mathbf{1 0 0 , 0 \%}$ \\
\hline
\end{tabular}

Fonte: Câmara dos Deputados/Comissão de Orçamento e Controle Financeiro.

Contudo, nem sempre o governo está em condições de levar a cabo essa estratégia de premiar os deputados no fim de cada ano fiscal, tomando como referência o modo como eles votaram. Mesmo depois de esgotar todos os mecanismos institucionais para incentivar os deputados a apoiar seus projetos, o governo eventualmente tem de autorizar mais cedo a execução dos pedidos e projetos dos parlamentares, seja para resolver votações nominais controvertidas, seja para barrar iniciativas indesejáveis da oposição. Uma situação dessas ocorreu em maio de 2000, quando o Congresso tentou aumentar o salário mínimo além do nível desejado pelo governo. Conforme se pode verificar no Gráfico 1, o pico da liberação de emendas individuais (R\$ 133 milhões) ocorreu justo no mês em que o aumento estava sendo votado. 
Gráfico 1

“Restos a Pagar" Executados em 2000 e 2001

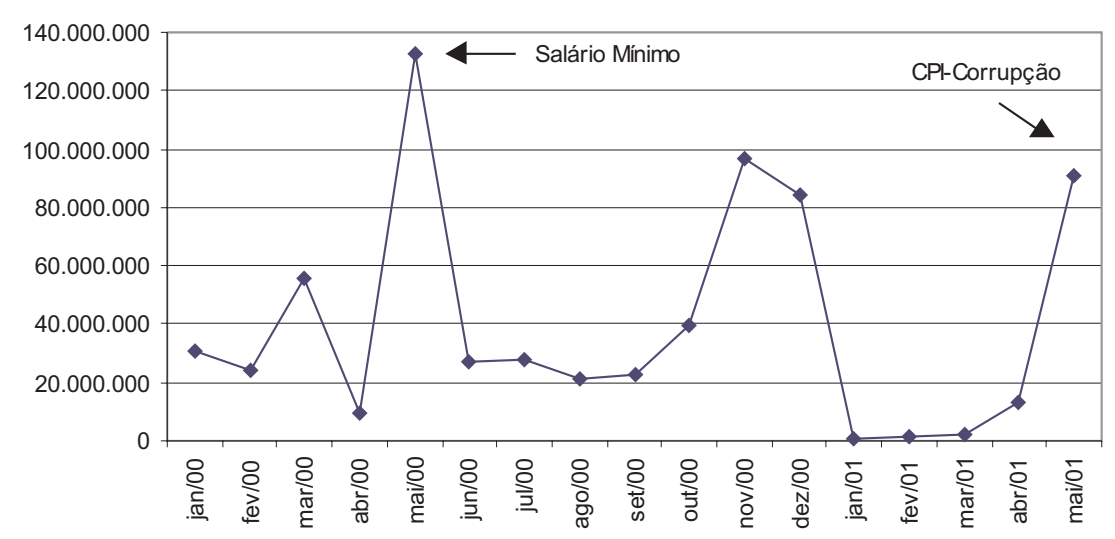

O governo tradicionalmente anuncia em $1^{\circ}$ de maio o novo salário mínimo. Mas em 2000 o debate foi antecipado para março, porque a Comissão Especial do Salário Mínimo da Câmara dos Deputados, dominada pelo PT, se uniu com o presidente do Congresso (e também o principal líder do PFL), o senador Antônio Carlos Magalhães, e decidiram aprovar um aumento de $30 \%$ do salário mínimo, equivalente a US\$100, enquanto a proposta do governo concedia um reajuste máximo de $11,3 \%$. Quando o presidente percebeu que iria perder a discussão no Congresso, resolveu decretar o salário mínimo por Medida Provisória em 23 de março, mais de um mês antes da data usual.

Foi uma decisão extremamente impopular porque coincidiu com o momento em que o governo estava negociando um aumento de $43 \%$ para o teto dos salários dos funcionários do primeiro escalão, inclusive os juízes. Para piorar ainda mais a situação, é importante lembrar que 2000 era um ano de eleições municipais, o que poderia trazer grandes prejuízos eleitorais para os parlamentares que apoiassem a proposta de salário mínimo do presidente e estivessem concorrendo a prefeituras. (De acordo com O Estado de S. Paulo, de 11/5/2001, 144 parlamentares já tinham anunciado pré-candidaturas a prefeito.) Como a Medida Provisória precisava ser votada pelo Congresso no prazo de trinta dias (ou ser reeditada pelo Executivo) para se tornar lei, ACM e a oposição perceberam que esta era uma excelente oportunidade para derrubar a MP no Congresso. 
Ante a ameaça de uma derrota - cerca de noventa congressistas da coalizão presidencial já tinham declarado que iriam votar contra a proposta do presidente (O Estado de S. Paulo, 20/4/2000) -, o governo concentrou esforços no adiamento da votação nominal da matéria a fim de ganhar tempo para reconstruir sua base de sustentação parlamentar. Manobrando com o regulamento da Câmara, o Executivo conseguiu postergar a decisão para maio. Enquanto isso, para restabelecer sua maioria parlamentar, o presidente teve de atender aos pedidos dos parlamentares, desembolsando recursos mediante a liberação de emendas individuais. Em 10 de maio de 2001, o governo finalmente conseguiu aprovar a Medida Provisória sobre o salário mínimo no nível que pretendia, obtendo uma maioria extraordinária de 305 deputados e 48 senadores.

Um bom exemplo do bloqueio de uma legislação indesejável ocorreu em maio de 2001, quando a oposição tentou criar uma Comissão Parlamentar de Inquérito - CPI para investigar denúncias de corrupção no governo. Desde o começo do ano, o Executivo vinha seguindo seu ritmo gradual de desembolsos dos "restos a pagar" de 2000 (veja novamente o Gráfico 1). Em janeiro, por exemplo, o nível de liberação de verbas foi de cerca de R $\$ 500$ mil; em fevereiro, esse valor subiu para $\mathrm{R} \$ 1,33$ milhão e, em março, chegou a aproximadamente $\mathrm{R} \$ 1,97 \mathrm{mi}$ lhão. Em abril, quando o governo percebeu que havia um risco sério de instalação da CPI, acelerou o ritmo dos desembolsos para cerca de R\$13,2 milhões. Já na segunda semana de maio, depois que o principal partido de oposição anunciou ter alcançado o número necessário de assinaturas ao requerimento de instalação da CPI (171 deputados e 27 senadores), o desembolso pulou para mais de $\mathrm{R} \$ 90$ milhões. Apesar de trazer alguns custos políticos, a estratégia foi muito eficaz, pois vinte deputados que pertenciam a partidos integrantes da coalizão governamental retiraram suas assinaturas e a CPI foi abortada ${ }^{18}$.

À primeira vista, pode parecer que a soma de dinheiro despendida pelo governo para manter a disciplina de sua coalizão é muito alta. Mas, comparando a totalidade de recursos destinados a investimentos com os outros gastos do governo, percebe-se que, na realidade, aqueles desembolsos correspondem a uma pequena fração do total. $O$ valor gasto com investimentos, rubrica onde estão localizadas as verbas vinculadas a emendas dos parlamentares, e efetivamente liberado entre 1998 e 2000, significou menos de 2\% (em 2001 um pouco acima deste patamar, $2,4 \%$ ) de toda a despesa do governo (veja a Tabela 
3). Os recursos orçamentários destinados ao pagamento e refinanciamento das dívidas, às transferências constitucionais aos estados e municípios e à seguridade social, e os relacionados com os gastos operacionais dos órgãos públicos não podem ser tocados pelo Congresso no processo de elaboração do orçamento. Assim, o montante que sobra para as emendas individuais e coletivas dos parlamentares é extremamente baixo. Em outras palavras, as ações dos parlamentares na esfera orçamentária são limitadas e condicionadas pelas iniciativas do Executivo. Vimos na seção anterior que essas restrições funcionam como proteção e garantia de que o Congresso não mudará aspectos mais relevantes da proposta orçamentária do governo.

Por outro lado, nem todos os recursos destinados à rubrica investimentos correspondem a emendas dos parlamentares. Na realidade, é muito difícil obter um valor exato e confiável. Uma das principais razões disso é que algumas emendas à proposta original do Executivo são agregadas. Por exemplo, se um parlamentar obtém aprovação de uma emenda de $\mathrm{R} \$ 100$ mil a um subprojeto original de $\mathrm{R} \$ 15$ milhões, a execução vai aparecer agregada como se o autor da emenda tivesse obtido a quantia total e não apenas a parcela específica que ele acrescentou. O Executivo também pode aproveitar um projeto (ou a emenda) apresentado por um único parlamentar para redistribuir verbas por créditos adicionais e, assim como no caso anterior, sua liberação será agregada.

De maneira geral, entre $18 \%$ e $25 \%$ do total de recursos alocados a investimentos relaciona-se com emendas parlamentares individuais ou coletivas. Desde a adoção da cota de $\mathrm{R} \$ 1,5$ milhão por parlamentar, há cinco anos atrás, o valor máximo da soma total das emendas individuais é de $R$ \$ 871,5 milhões (581 parlamentares, entre deputados e senadores, vezes $\mathrm{R}$ \$ 1,5 milhão). De acordo com a Comissão de Controle Financeiro, o montante das verbas alocadas como emendas coletivas é de aproximadamente $\mathrm{R} \$ 3,5$ bilhões por ano, dos quais $70 \%$ se destinam a investimentos. Em outras palavras, a quantia dedicada às emendas é muito reduzida, se comparada com os outros gastos orçamentários do governo.

Outras indicações da utilização estratégica das emendas individuais podem ser verificadas pela observação do padrão de distribuição desses recursos. Esse padrão se tem mantido durante o segundo mandato de Fernando Henrique. A Tabela 4 mostra que os partidos políti- 
Tabela 3

Descrição das Despesas Orçamentárias (1998-2001)

\begin{tabular}{|c|c|c|c|c|c|c|c|c|}
\hline & 1998 & $\%$ & 1999 & $\%$ & 2000 & $\%$ & 2001 & $\%$ \\
\hline Pessoal & 47.947 & 9,6 & 51.571 & 8,8 & 58.241 & 9,5 & 65.449 & 10,9 \\
\hline Seguridade social & 53.511 & 10,7 & 58.159 & 9,9 & 64.710 & 10,5 & 74.857 & 12,4 \\
\hline Juros da dívida interna & 25.432 & 5,1 & 37.018 & 6,3 & 38.835 & 6,3 & 52.816 & 8,8 \\
\hline Juros da dívida externa & 5.380 & 1,1 & 8.337 & 1,4 & - & - & - & - \\
\hline Transferências municipais e estaduais & 37.509 & 7,5 & 41.919 & 7,1 & 51.575 & 8,4 & 59.841 & 9,9 \\
\hline Outros custos operacionais & 29.563 & 5,9 & 31.331 & 5,3 & 36.640 & 5,9 & 40.763 & 6.8 \\
\hline Investimentos & 8.346 & 1,7 & 6.955 & 1,2 & 10.099 & 1,6 & 14.580 & 2,4 \\
\hline Investimentos de capital & 71.344 & 14,3 & 56.822 & 9,7 & 11.421 & 1,9 & 20.446 & 3,4 \\
\hline Amortização da dívida & 221.151 & 44,2 & 296.424 & 50,4 & 344.862 & 56,0 & 274.681 & 45,5 \\
\hline - Parcela da dívida rolada & 196.740 & 39,3 & 269.242 & 45,8 & 300.962 & 48,8 & 220.046 & 36,5 \\
\hline - Parcela da dívida amortizada & 24.411 & 4,9 & 27.182 & 4,6 & 43.900 & 7,1 & 54.635 & 9,1 \\
\hline Total & 500.183 & & 588.536 & & 616.383 & & 603.433 & \\
\hline
\end{tabular}

Fonte: Câmara dos Deputados/Comissão de Orçamento e Controle Financeiro. 
cos que formam a coalizão presidencial no Congresso foram muito bem recompensados pelo governo na execução orçamentária de 2000. Os parlamentares ligados aos cinco partidos (PSDB, PFL, PMDB, PPB e PTB) integrantes da coalizão presidencial receberam $83,8 \%$ da totalidade dos recursos públicos que foram executados como emendas individuais no ano de 2000, enquanto os partidos da coalizão de governo detinham $73,7 \%$ das cadeiras na Câmara dos Deputados. OPTB foi o que recebeu a menor parcela, $4,8 \%$ do total desembolsado no ano inteiro. Este valor foi menor do que o liberado para os deputados do principal partido de oposição, o PT, que recebeu 6,1\%. Mas levando em conta que o PTB tem apenas 6,0\% das cadeiras na Câmara, sua cota de desembolsos foi proporcional ao tamanho do partido. O PT, por sua vez, que detém 58 das cadeiras da Câmara dos Deputados em 1998 (11,3\%), não recebeu montante equivalente às suas dimensões. Este dado permite inferir que o Executivo brasileiro adota duas estratégias no processo de distribuição de verbas orçamentárias: a primeira é a de recompensar os deputados que pertencem à sua coalizão e punir os que dela não fazem parte; a segunda é considerar o tamanho e a importância relativa dos partidos políticos que integram a coalizão presidencial. O melhor exemplo é o PMDB, cujos deputados receberam $23,1 \%$ do total de desembolsos, embora sua bancada ocupasse 16,2\% das vagas da Câmara no começo da legislatura de 1998.

Esse argumento se mostra com mais clareza na Tabela 5 que correlaciona três variáveis associadas aos partidos políticos que fazem parte da coalizão presidencial: porcentagem de emendas individuais liberadas pelo governo entre 1995 e 1998 e em 2000; número e porcentagem de cadeiras que cada partido controla na Câmara dos Deputados em 1994 e 1998; e média da disciplina partidária entre 1995 e 1998 (Nicolau, 2000) que, na realidade, serve como referência do apoio dado ao presidente, pois todos os cinco partidos já faziam parte da coalizão governamental atual.

Comparando todo o primeiro mandato do governo Fernando Henrique com apenas um ano (2000) do segundo mandato, os deputados filiados aos partidos integrantes da coalizão presidencial aumentaram a proporção de suas emendas liberadas de $72,4 \%$ para $83,7 \%$. As exceções foram o PTB e o PPB, cujas apropriações caíram, respectivamente, de $6,1 \%$ para $4,8 \%$ e de $15,7 \%$ para $10,3 \%$. Em outras palavras, o governo Fernando Henrique aprimorou a estratégia de recompensar ou punir parlamentares segundo a forma de votar no Congresso, haja 
Tabela 4

Execução de Emendas Individuais por Partidos

Políticos no Orçamento Federal Brasileiro - 2000

\begin{tabular}{l|c|c}
\hline Partido & Emendas Executadas & $\%$ \\
\hline PFL & 107.447 .515 & 23,3 \\
PMDB & 106.825 .693 & 23,1 \\
PSDB & 102.652 .276 & 22,2 \\
PPB & 47.685 .657 & 10,3 \\
PT & 28.178 .236 & 6,1 \\
PTB & 22.373 .311 & 4,8 \\
PDT & 12.177 .180 & 2,6 \\
PPS & 7.008 .076 & 1,5 \\
PSB & 6.736 .077 & 1,5 \\
PL & 5.750 .997 & 1,3 \\
PST & 4.930 .221 & 1,1 \\
PC do B & 4.225 .901 & 0,9 \\
PV & 1.499 .027 & 0,3 \\
Sem partido & 1.170 .000 & 0,3 \\
PSD & 959.999 & 0,2 \\
PHDBS & 939.000 & 0,2 \\
PSL & 690.000 & 0,2 \\
PMN & 570.000 & 0,1 \\
\hline Total & 461.819 .166 & $\mathbf{1 0 0 , 0 0}$ \\
\hline
\end{tabular}

Obs.: Posição em 13/1/2001.

Valores em R \$1,00.

vista que o aumento da execução de emendas individuais $(11,3 \%)$ foi proporcionalmente maior do que o número de cadeiras na Câmara em poder da coalizão governamental $(7,3 \%)$.

Cabe observar que o PMDB, apesar de ser o partido menos disciplinado da coalizão presidencial, recebeu a maior porcentagem de emendas individuais, 21,9\%. Apesar de perder algumas vagas na eleição de 1998, reduzindo sua bancada de 107 (20,9\%) deputados para 83 $(16,2 \%)$, o partido teve aumentada sua cota de execuções orçamentárias, que passou de $21,9 \%$ para $23,1 \%$. Este dado é mais expressivo quando se compara a porcentagem de execuções orçamentárias do PMDB $(80,1 \%)$ com as do PFL e do PSDB, partidos mais fiéis às preferências do presidente (93,4\% e 91,6\%, respectivamente). Embora os deputados pertencentes a estes partidos tivessem votado com mais regularidade a favor dos interesses do governo, obtiveram menos verbas do que o PMDB durante a primeira gestão de Fernando Henri- 
Tabela 5

Porcentagem de Execução de Emendas Individuais, Número de Cadeiras e Disciplina Partidária da Coalizão Presidencial

\begin{tabular}{l|c|c|c|c|c|c|c}
\hline Partido & $\begin{array}{c}\text { \% de Emendas } \\
\text { Individuais Exe- } \\
\text { cutadas 1995-98 }\end{array}$ & $\begin{array}{c}\text { \% de Emen- } \\
\text { das Indivi- } \\
\text { duais Execu- } \\
\text { tadas 2000 }\end{array}$ & $\begin{array}{c}\text { Cadeiras } \\
\mathbf{1 9 9 4}\end{array}$ & $\mathbf{\%}$ & $\begin{array}{c}\text { Cadeiras } \\
\mathbf{1 9 9 8}\end{array}$ & $\mathbf{\%}$ & $\begin{array}{c}\text { Média da } \\
\text { Disciplina } \\
\text { Partidária } \\
\mathbf{1 9 9 5 - 9 8}\end{array}$ \\
\hline PFL & 15,2 & 23,3 & 89 & 17,3 & 105 & 20,5 & $93,4 \%$ \\
PMDB & 21,9 & 23,1 & 107 & 20,9 & 83 & 16,2 & $80,1 \%$ \\
PSDB & 13,5 & 22,2 & 62 & 12,1 & 99 & 19,3 & $91,6 \%$ \\
PPB & 15,7 & 10,3 & 52 & 10,1 & 60 & 11,7 & $83,1 \%$ \\
PTB & 6,1 & 4,8 & 31 & 6,0 & 31 & 6,0 & $88,3 \%$ \\
\hline Total & $\mathbf{7 2 , 4}$ & $\mathbf{8 3 , 7}$ & $\mathbf{3 4 1}$ & $\mathbf{6 6 , 4}$ & $\mathbf{3 7 8}$ & $\mathbf{7 3 , 7}$ & \\
\hline
\end{tabular}

que. Uma possível explicação para este fato é que o PFL e o PSDB tinham o controle de menor número de cadeiras do que o PMDB nos primeiros quatro anos do atual governo. Logo que o PFL obteve mais vagas no Congresso, em conseqüência da eleição de 1998, elevou também suas apropriações orçamentárias a um patamar um pouco superior às do $\mathrm{PMDB}^{19}$.

\section{CONCLUSÕES}

Neste artigo analisamos o processo de elaboração do orçamento no Brasil e mostramos que o governo o mantém sob rígido controle. Normas e procedimentos institucionais garantem que o Executivo não corra o risco de ter sua proposta desfigurada pelos congressistas. $\mathrm{O}$ presidente não só pode vetar as mudanças indesejáveis impostas pelos parlamentares ao projeto original, como tem à disposição uma série de instrumentos institucionais e vantagens informacionais que lhe permitem guiar em segurança a tramitação do orçamento pelo Congresso. Como se isso não bastasse, certas normas resguardam as preferências do governo, colocando fora do alcance dos parlamentares as partes mais importantes do orçamento, porque lhes é permitido propor emendas apenas a uma parcela diminuta do pacote de despesas orçadas.

A despeito desse enorme controle, os legisladores propõem e aprovam um grande número de emendas ao orçamento anual. Embora os valores dessas emendas sejam muito pequenos em relação à totalidade do orçamento, é surpreendente que, dispondo de tantos instru- 
mentos, o Executivo deixe que sua proposta se desvie tanto dos termos que gostaria. Alegamos que o governo se dispõe a arriscar esse custo, porque se aproveita da oportunidade para utilizar a execução de emendas como instrumento de controle dos membros de sua coalizão nas votações no Congresso. Em outras palavras, o uso estratégico da liberação das emendas propicia ao Executivo o ganho de votos favoráveis que mais do que compensa a perda decorrente da alteração de sua proposta inicial. É por isso que o governo não somente abre mão de usar os recursos institucionais e as informações de que dispõe para impedir a modificação do seu projeto de orçamento, como incentiva a apresentação de emendas ao sistematicamente superestimar o nível das receitas esperadas. Não que os congressistas sejam ludibriados por essa estratégia; eles se dispõem a participar desse jogo com o governo porque vêem nele um meio através do qual a maioria dos parlamentares possa assegurar sua própria sobrevivência política. Os deputados que fazem parte da coalizão se beneficiam recebendo verbas orçamentárias que, apesar de pequenas em relação à totalidade do orçamento, são suficientes para garantir-lhes êxito eleitoral e sobrevivência política (Pereira, 2000; Pereira e Rennó, no prelo).

Dessa maneira, em vez de acarretar grandes déficits públicos, o governo de presidencialismo de coalizão no Brasil propicia condições para que o Executivo obtenha, a um baixo custo, alto grau de governabilidade. A gama de recursos institucionais que conferem ao Executivo o controle do processo de elaboração e execução do orçamento federal contrabalança as possíveis fragilidades dos seus sistemas eleitoral, partidário e federativo tantas vezes apontados pela literatura como responsáveis pelas mazelas e problemas governativos no Brasil.

(Recebido para publicação em março de 2002) 


\section{NOTAS}

1. Alesina e outros (1999:255) chegam a resultados similares tanto para países da OCDE como para a América Latina. Entretanto, para estes autores o que determina o tamanho do déficit é a "natureza dos procedimentos orçamentários". Ou seja, procedimentos que limitam o papel dos legisladores e atribuem maior poder a um ator individual (i. e. Tesouro Nacional) tenderiam a produzir um menor déficit primário. Por outro lado, quanto mais colegiada e aberta for a decisão sobre o orçamento, maior o déficit e mais ineficiente será o orçamento (Baron, 1991:57). Para uma análise específica das restrições dos procedimentos orçamentários no caso chileno, ver Baldez e Carey (2001).

2. Para uma ótima fonte de informações sobre os termos e procedimentos orçamentários, ver Sanches (1997).

3. O Plano Plurianual é elaborado pelo Executivo quatro meses antes do fim do primeiro ano de seu mandato; ele define as prioridades estratégicas do governo federal no longo prazo, funcionando como uma espécie de arcabouço institucional para o planejamento das despesas e das políticas governamentais. O Plano deve ser analisado, emendado e aprovado pelo Congresso até o último mês do primeiro ano do seu mandato e é válido até o fim do primeiro mês do próximo governo eleito. A Lei de Diretrizes Orçamentárias é renovada anualmente e precisa ser enviada pelo Executivo ao Congresso até o primeiro quarto do segundo ano de gestão governamental. O Congresso deve sancioná-la até junho do mesmo ano. De acordo com o artigo 35 do Ato das Disposições Constitucionais Transitórias - ADCT, o Executivo deve enviar a LDO até 15 de abril de cada ano e o Congresso deve votá-la e devolvê-la até 30 de junho do mesmo ano. A LDO é o principal mecanismo institucional de orientação para a formulação de políticas públicas, porque define as prioridades a serem incluídas na Lei Orçamentária Anual do ano fiscal seguinte.

4. No Brasil, o Executivo tem o direito de veto sobre a proposta de orçamento aprovada pelo Congresso em parte ou no todo.

5. A receita é classificada de duas maneiras: impostos, que são conseqüência da arrecadação tributária, contribuições e recursos financeiros; e receita de capital, que resulta das operações de crédito e do superávit da receita fiscal.

6. O artigo 166, § único, da Constituição Federal define as seguintes atribuições à CMPOF: "I - examinar e emitir parecer sobre os projetos referidos neste artigo [PPA, LDO, LOA e créditos adicionais], e sobre as contas apresentadas anualmente pelo presidente da República; II - examinar e emitir parecer sobre os planos e programas nacionais, regionais e setoriais previstos nesta Constituição e exercer o acompanhamento e a fiscalização orçamentária, sem prejuízo da atuação das demais comissões do Congresso Nacional e suas Casas [...]".

7. O grau exacerbado de competição entre parlamentares para fazer parte da Comissão Mista de Orçamento levou a freqüentes aumentos no número de vagas na CMPOF. Em 1988, havia 60 membros titulares (45 deputados e 15 senadores) e hoje são 84 (63 deputados e 21 senadores). Na opinião de Serra (1994), o aumento do número de membros da CMPOF foi a maneira que os líderes partidários encontraram para lidar com as pressões dos parlamentares, já que a mera participação na comissão aumenta consideravelmente as chances de ter projetos aprovados. 
8. Segundo este mesmo jornal, o campeão de "rachadinhas" no ano de 2001 foi o Estado de Mato Grosso. A bancada - de oito deputados e três senadores - apresentou quinze emendas, das quais treze são genéricas. Do total de $\mathrm{R} \$ 800$ milhões propostos, R\$ 650 milhões (81\%) são para emendas genéricas. O deputado Ricarte de Freitas (PSDB-MT), coordenador da bancada, afirma que "sempre fizemos isso. As emendas são genéricas mesmo. Depois de definido o valor, avaliamos para quem vai o dinheiro, assim conseguimos mais recursos para o maior número de municípios" (Folha de S. Paulo, Caderno Brasil, 13/11/2001).

9. Em 1989, por exemplo, o número de emendas individuais foi 11 mil; em 1999, 13 mil; em 1991,71 mil; em 1992, 76 mil; em 1993, 13 mil; em 1994, 23 mil (Rocha, 1997).

10. Se A se importasse apenas com a política 1 e B com a política 2, suas curvas de indiferença seriam verticais e horizontais, respectivamente.

11. Pode parecer estranho neste exemplo que a restrição não se estenda à configuração final do orçamento previsto. Esperava-se que todos os partidos concordassem com uma configuração diferente que fosse satisfatória para todos. Isso se deve aos pontos preferidos específicos que foram escolhidos pelos três congressistas. A preferência do congressista $C$ é que faz os resultados caírem abaixo da restrição. Na maioria das vezes, é de se esperar que a maior parte dos parlamentares prefira pontos bem acima da restrição de modo que eles venham a ser obrigatórios.

12. No Brasil, o governo normalmente anuncia a sua posição sobre um projeto de lei, por intermédio do seu líder no Congresso, antes da votação no plenário.

13. Todas as variáveis são construídas com dados do Congresso Nacional para os anos de 1995 a 1998.

14. Estatística descritiva sobre os dados:

\begin{tabular}{l|c|c|c|c}
\hline Variável & Média & Desvio-Padrão & Mínimo & Máximo \\
\hline Votos & 76,607 & 25,760 & 4,762 & 100,00 \\
Apropriação & 38,702 & 19,154 & 0,00 & 100,00 \\
Número de emendas & 3,16 & 4,012 & 0,00 & 27,00 \\
Antiguidade & 1,938 & 1,287 & 1,00 & 8,00 \\
Cargo & 0,310 & 0,463 & 0,00 & 1,00 \\
Concentração & 37,780 & 22,598 & 2,73 & 93,46 \\
Esquerda & 0,207 & 0,405 & 0,00 & 1,00 \\
Centro & 0,375 & 0,485 & 0,00 & 1,00 \\
\hline
\end{tabular}

15. Cabe notar que no Brasil o distrito eleitoral de um deputado é todo o estado.

16. Usamos as seguintes variáveis como instrumentos: uma variável dummy equivalente a 1 quando o deputado participou da coalizão governante durante o período; uma variável dummy igual a 1 se o deputado saiu da coalizão; o número de vezes que ele trocou de partido; uma variável dummy igual a 1 se o deputado já exerceu outros cargos eletivos; uma variável dummy igual a 1 se o deputado é do mesmo partido do governador; uma variável dummy igual a 1 se o deputado pertence à coalizão dos prefeitos de seus principais redutos eleitorais. As duas últimas variáveis procuram apreender a influência dos atores políticos regionais e municipais que 


\section{Carlos Pereira e Bernardo Mueller}

controlam recursos políticos, como verbas públicas e cargos, sobre a maneira de votar do deputado.

17. Entrevista realizada com Eduardo Graeff, em Brasília, em setembro de 1997.

18. Um dia antes de retirar sua assinatura do requerimento da CPI da corrupção, a emenda de R \$ 80 mil apresentada pelo deputado Oliveira Filho (PL-PR) para atender a necessidades de sua principal base eleitoral, a cidade de Floraí-PR, foi liberada. O mesmo sucedeu com a emenda de R\$ 103 mil do deputado Augusto Nardes (PPB-RS) para seu distrito mais importante; com R $\$ 389$ mil para as emendas do deputado Robério Araújo (PL-RR); com R\$ 82 mil do deputado Eujácio Simões (PFL-BA); com R\$ 69 mil do deputado Ursicino Queiroz (PFL-BA); com R\$ 260 mil do deputado Luiz Moreira (PFL-BA). Mas o deputado mais eficiente de todos foi Luciano Bivar (PSL-PE) que condicionou a retirada do seu nome do requerimento da CPI à liberação de sua emenda de R 1 milhão para beneficiar seu mais importante reduto eleitoral, Jaboatão dos Guararapes (Folha de S. Paulo, 12/5/2001).

19. Outros fatores, certamente, influem no comportamento estratégico dos partidos dentro da coalizão. Principalmente, há possibilidade de risco moral quando os partidos da coalizão que mais se desviam se habilitam a recompensas maiores. Um exemplo foi a recompensa dada pelo governo ao PMDB, partido que muitas vezes votou contra os projetos de interesse do Executivo. Por não se posicionar sempre favoravelmente aos projetos do Executivo, especialmente em votações nominais controversas, contrariamente à posição do PSDB e do PFL, o PMDB tornou-se o eleitor decisivo, "o voto de Minerva", e com isso aumentou o preço do seu voto (Groseclose e Snyder, 1996). Entretanto, esse aspecto não será abordado neste artigo.

\section{REFERÊNCIAS BIBLIOGRÁFICAS}

ALESINA, A., HAUSMANN, R., HOMMES, R. e STEIN, E. (1999), “Budget Institutions and Fiscal Performance in Latin America". Journal of Development Economics, vol. 59, pp. 253-273.

ALSTON, L. J. e MUELLER, B. (2001), Gains from Trade between the Executive and the Legislature in Brazil. Manuscrito.

AMES, Barry. (2001), The Deadlock of Democracy in Brazil. Ann Arbor, The University of Michigan Press.

BALDEZ, L. e CAREY, J. (2001), “Budget Procedure and Fiscal Restraint in Posttransition Chile", in S. Haggard e M. McCubbins (eds.), Presidents, Parliaments, and Policy. Cambridge, Cambridge University Press.

BARON, D. (1991), "Majoritarian Incentives, Pork Barrel, and Procedural Control". American Journal of Political Science, vol. 35, nำ1, pp. 57-90. 
BEZERRA, M. O. (1999), Em Nome das Bases: Politica, Favor e Dependência Pessoal. Rio de Janeiro, Relume-Dumará.

CASTROSANTOS, M. H. e MACHADO, E. M. (1995), “O Jogo Orçamentário da União: Relações Executivo-Legislativo na Terra do Pork-Barrel". ENAP - Relatório Interno, no 7 .

FIGUEIREDO, A. e LIMONGI, F. (2000), Executivo e Legislativo na Formulação e Execução do Orçamento Federal. Trabalho apresentado na reunião anual da Associação Brasileira de Ciência Política - ABCP, São Paulo.

GROSECLOSE, T. e SNYDER, J. (1996), "Buying Supermajorities". American Political Science Review, vol. 90, nํ2, pp. 303-315.

INMAN, R. e FITTS, M. (1990), “Political Institutions and Fiscal Policy: Evidence from the US Historical Record". Journal of Law, Economics and Organization, vol. 6 (special issue), pp. 79-132.

LIJPHART, A. (1994), Electoral System and Party Systems. Oxford, Oxford University Press.

MAINWARING, S. (1999), Rethinking Party Systems in the Third Wave of Democratization: The Case of Brazil. Stanford, Stanford University Press.

NICOLAU, J. (2000), “Disciplina Partidária e Base Parlamentar na Câmara dos Deputados no Primeiro Governo Fernando Henrique Cardoso (1995-1998)". Dados, vol. 43, no 4, pp. 709-735.

PEREIRA, C. (2000), What Are the Conditions for the Presidential Success in the Legislative Arena? The Brazilian Electoral Connection. Ph.D. Dissertation, The New School University, New York.

_e MUELLER, B. (2000), “Uma Teoria da Preponderância do Executivo: O Sistema de Comissões no Legislativo Brasileiro". Revista Brasileira de Ciências Sociais, vol. 15 , no 43, pp. 45-67.

PEREIRA, C. e RENNÓ, L. (no prelo), “Successful Re-election Strategy in Brazil: The Electoral Impact of District Institutional Incentives". Electoral Studies: An International Journal.

POTERBA, J. (1994), "State Response to Fiscal Crises: The Effects of Budgetary Institutions and Politics". Journal of Political Economy, vol. 102, no 4, pp. 799-821.

ROCHA, P. (1997), Congresso Nacional e Orçamento Público. O Processo Decisório na Fase Legislativa do Ciclo Orçamentário Ampliado. Dissertação de Mestrado, UnB, Brasília.

— e MACHADO, E. M. (1995), “O Processo Orçamentário da União e as Políticas Públicas no Brasil". ENAP - Relatório Interno, no 5 .

ROUBINI, N. e SACHS, J. (1989), “Political and Economic Determinants of Budget Deficits in the Industrial Countries". European Economic Review, vol. 33, pp. 903-938.

SANCHES, O. (1997), Dicionário de Orçamento, Planejamento e Áreas Afins. Brasília, Prisma. 
SCARTASCINI, C. e CRAIN, W. (2001), The Size and Composition of Government Spending in Multi-Party Systems. Trabalho apresentado na Public Choice Society Conference, San Antonio, Texas.

SERRA, J. (1994), Orçamento no Brasil. Raízes da Crise. São Paulo, Atual Editora.

SHEPSLE, K. A. e WEINGAST, B. R. (1981), "Structure-Induced Equilibrium and Legislative Choice". Public Choice, vol. 37, pp. 503-519.

STEIN, E., TALVI, E. e GRISANTI, A. (1998), “Institutional Arrangements and Fiscal Performance: The Latin America Experience". NBER Working Papers Series, $\mathrm{n}$ 은 6358.

WEINGAST, B. (1979), "A Rational Choice Perspective on Congressional Norms". American Journal of Political Science, vol. 23, nํ2, pp. 245-262.

WHITE, H. (1980), "A Heteroscedasticity-Consistent Covariance Matrix Estimator and a Direct Test for Heteroscedasticity". Econometrica, vol. 48, pp. 817-838.

\section{ABSTRACT}

Strategic Behavior in a Coalition-Based Presidential System:

Executive-Legislative Relations in the Budgetary Process in Brazil

In Brazil the executive has exclusive rights to initiate the annual budget. Legislators have the right to amend the bill; but only if those amendments are compatible with the multi-year budget plan elaborated by the executive as well as with the law on budgetary guidelines. Moreover, congress may not authorize expenditures that exceed the budgetary revenue. It is also the executive, who is entitled to determine which amendment will really be appropriated, as the appropriation is contingent on the availability of resources in the national treasury. This paper argues that those rules not only restrict congressional action, but also enable the president to preserve at low costs its coalition inside Congress. It shows strong evidence that the Brazilian President rewards those legislators who most vote for his interests by executing their individual amendments to the annual budget and, equally, punishes those who vote less by not executing their individual amendments.

Key words: executive-legislative; Brazil; budgetary process; coalition-based presidential system 
RÉSUMÉ

Stratégie de Conduite dans un Système Présidentiel Basé sur la

Coalition: Rapports entre l'Exécutif et le Législatif dans le Processus

Budgétaire au Brésil

Au Brésil, le pouvoir exécutif a les droits exclusifs d'inaugurer le budget annuel. Le législateur n'a le droit de proposer des amendements au projet de loi que si ses amendements sont compatibles avec le plan de budget pluriannuel élaboré par l'exécutif et avec la loi de l'ordre du jour budgétaire. En outre, le congrès peut ne pas autoriser des dépenses dépassant la recette budgétaire. C'est toujours l'exécutif qui peut déterminer quels sont les amendements effectivement appropriés, puisque l'affectation des fonds dépend de l'existence de ressources dans le trésor national. Dans cet article, on montre que toutes ces dispositions non seulement restreignent l'action du Congrès, mais aussi permettent au président de maintenir à peu de frais la coalition dans le Congrès. Il y a des signes évidents des récompenses que le président du Brésil offre aux législateurs qui votent souvent en sa faveur lorsqu'il fait ses amendements individuels au budget annuel et, de même, lorsqu'il punit ceux qui votent contre ses amendements.

Mots-clé: exécutif-législatif; Brésil; processus budgétaire; système présidentiel basé sur la coalition 